9. Все, что в сердце. Художники Красноярья вчера, сегодня, завтра / [авт.-сост. М. В. Москалюк]. Красноярск: Поликор, 2010. - 228 с.

10. Художники Тюмени : [юбилейный альбом : 50-летию Тюменской организации Союза художников России посвящается] / [авт. ст. А. А. Валов, Н. И. Сезева, Н. Н. Шайхтдинова]. - Тюмень : Тюмен. обл. орг-я Союза художников России, 1994. - 197 с. : ил.

11. Кирилова, Г. С. Владимир Федорович Стожаров.-Ленинград: Художник РСФСР, 1974.-78 с. : ил.

12. Павел Судаков : Живопись. Графика : альбом / П. Л. Проскурин, В. И. Фирсов. - Москва : Советская Россия, 1980. - 199 с. : ил.

Sergei A. Zhuk, Ph. D. in Art Criticism, Associate Professor Altai State Institute of Culture (Barnaul, Russia) sergei.zhuk2010@mail.ru

\title{
GENRE PATTERNS IN MOUNTAIN SCENERIES BY SIBERIAN PAINTERS
}

\begin{abstract}
The paper discloses the main plot, coloristic, and compositional decisions of paintings in mountain scenery genre made by prominent Siberian artists of the $19^{\text {th }}$ and $20^{\text {th }}$ centuries, such as: Grigory Gurkin, Nikolai Ivanov, Valentin Kurzin, Mikhail Budkeev, Yuri Korobeinikov, Sergei Kashkarov, Zaur Ibragimov, Yuri Bralgin, Ilse Rudzite, Leopold Tsesiulevich, Boris Riauzov, Anatolii Znak, Toivo Riannel, Anton Dovnar, Aleksandr Kalinin, Vladimir Kapelko, Vladimir Stozharov, Pavel Sudakov). The author outlines his opinion on specifics of masters' individual creative manners of imaging epic landscapes of Siberia and Altai, relations between a human and nature; the specifics of Siberian masters' artistic, expressive means and painting techniques are set out.

Keywords: a plot in landscape painting, genre patterns, plain air painting, a mountain scenery, natural scenery, "the second environment" in landscape painting.
\end{abstract}

УДК 75.035(470)9“187/192”

DOI: $10.32340 / 2414-9101-2020-1-57-65$

Е. А. Скоробогачева, доктор искусствоведения Российская академия живописи, ваяния и зодчества Ильи Глазунова (Москва, Россия) skorobogacheva@mail.ru

\section{ТРАДИЦИОННАЯ КУЛЬТУРА РУССКОГО СЕВЕРА В ГЕНЕЗИСЕ НЕОРУССКОГО СТИЛЯ}

Аннотация. Охарактеризован историко-культурный контекст возникновения в отечественном искусстве рубежа XIX-XX вв. неорусского стиля, занятого творческим переосмыслением художественных традиций древнерусского изобразительного искусства. Представлена авторская оценка роли системы изобразительно-выразительных средств народного искусства Русского Севера в становлении эстетических канонов неорусского стиля. Проанализированы ключевые особенности художественного языка крупнейших отечественных художников, работавших в неорусском стиле: В. М. Васнецова (1848-1926 гг.), М. В. Нестерова (1862-1942 гг.), И. Я. Билибина (1876-1942 гг.).

Ключевые слова: Русский Север, русская народная культура, художественный язык народного изобразительного искусства Русского Севера, Виктор Васнеиов (русский художник), Михаил Нестеров (русский художник), Иван Билибин (русский художник), неорусский стиль, модерн, православное христианство в светском искусстве. 
Отечественное искусство рубежа XIX-XX вв. пережило бурный расцвет неорусского стиля - самобытного направления в русле модерна, положившего в основу художественного поиска мотивы, символы и образы русской культуры, национальной духовной жизни. Вопрос о прямой принадлежности неорусского стиля к корпусу течений модерна относится к числу дискуссионных; историки и теоретики искусства, искусствоведы по-разному характеризуют его идейные истоки, дают неоднозначные, - порой, полярные - оценки творчеству его ведущих представителей. В статье мы попытаемся раскрыть значение народной культуры северных регионов Европейской части России, традиционно именуемых Русским Севером, сложившейся в XVI-XVII вв., в генезисе неорусского стиля.

Обратимся к характеристике исторических процессов, которые способствовали зарождению неорусского стиля. Повышенный интерес представителей российских художественных кругов к национальным идеям, к образцам древнего отечественного искусства и к русскому фольклору в целом, сформировавшийся под влиянием, в частности, специфики политического момента и широкого распространения идеологии народничества, сохранялся в течение всего XIX в. Появление этой тенденции в начале XIX в. следует связывать с первой реакцией авангарда творческих сил государства на распространение русофобских настроений в обществе, ставшего следствием доминирования европейского культурного влияния в XVIII в. В эпоху правления Петра I (1682-1721 гг.), Екатерины II (1762-1796 гг.) и Павла I (17961801 гг.); появление и распространение народных мотивов в изобразительном искусстве в период правления императора Александра I (1801-1825 гг.) обусловлено, прежде всего, резким подъёмом патриотических настроений в народной массе в период победоносной Отечественной войны 1812 г.

Общественные настроения второй четверти XIX в. - в период правления императора Николая I (1825-1855 гг.) - приобретают выраженную антизападническую ориентацию, в моду входит осуждение вольтерьянства и вольнодумства, широкую государственную поддержку и поощрение получают национальные идеи в культуре, изобразительном искусстве. Именно в годы царствования Николая I русский композитор М. И. Глинка (1804-1857 гг.) создаёт оперу патриотического содержания «Жизнь за иаря» (другое название - «Иван Сусанин», 1836 г.), славяновед и фольклорист А. Ф. Гильфердинг (1831-1972 гг.) и литератор и педагог Е. И. Классен (1795-1862 гг.) публикуют научные труды и дидактические материалы по истории древних славян, российского государства. Русский поэт, драматург и прозаик А. С. Пушкин (1799-1837 гг.) работает над произведениями, составившими «золотой фонд» национальной литературы. Императрица Александра Фёдоровна (1798-1860 гг.), супруга Николая I, позирует художникам в одеждах, стилизованных под русский народный женский костюм («Портрет императрищьы Александры Фёдоровныл» (худ. А. Малюков, 1836 г.; Россия, Государственный Эрмитаж), «Портрет императрищь Александры Фёдоровны, супруги Николая I (1798-1860)» (неизв. худ., копия с портр. Ф. Крюгера, сер. XIX в.; Россия, Государственный музе-заповедник «Гатчина»), «Портрет императрицы Александры Федоровны, жены императора Николая I» (неизв. худ.; вт. четв. ХІХ в; Россия, Государственный Русский музей)).

Во второй половине XIX в. развернулась до сих пор не потерявшая своей актуальности полемика двух оппозиционных друг другу идейно-философских течений: западничества и славянофильства. Наиболее радикально настроенные представители лагеря «западников» стремились к революционным преобразованиям государственного строя во имя прогресса по путям Западной Европы; идейные лидеры «славянофилов», напротив, настаивали на признании исключительной самобытности отечественного исторического, политического и духовного пути, горячо приветствуя национальный колорит в культуре, изобразительном искусстве. Ключевые приоритеты государственной политики российских императоров Александра II (царя-Освободителя), Александра III (царя-Миротворца), Николая II (царственного мученика, царя-страстотерпца, причисленного Русской Православной Церковью к 
лику святых) - носили национально-ориентированный, патриотический характер. Мятежные настроения в дореволюционном российском обществе находили своё отражение в изобразительном искусстве, ставшем полем ожесточённой битвы альтернативных взглядов на перспективы исторического развития государства.

В литературе кульминацией идейной борьбы стали выдающиеся прозаические произведения Ф. М. Достоевского (1821-1881 гг.) и Л. Н. Толстого (1828-1910 гг.), А. Н. Островского (1823-1886 гг.) и П. И. Мельникова-Печерского (1818-1883 гг.), поэтические сочинения Ф. И. Тютчева (1803-1873 гг.), Н.А.Некрасова (1921-1877 гг.), А. В. Кольцова (18091842 гг.), философские, богословские и публицистике труды А. С. Хомякова (1804-1860 гг.), И. А. Ильина (1883-1954 гг.), Н. Ф. Фёдорова (1829-1903 гг.), С. Н. Дурылина (18861954 гг.), ставшие национальным вкладом в классику мировой литературы. Изобразительное искусство заявило о своей приверженности народно-патриотическим идеям вдохновенными полотнами В. И. Сурикова (1848-1916 гг.), И. Е. Репина (1844-1930 гг.), В. Г. Перова (18331882 гг.), А. К. Саврасова (1830-1897 гг.), В. М. Васнецова (1848-1926 гг.), М. А. Врубеля (1856-1910 гг.), М. В. Нестерова (1862-1942 гг.), А. П. Рябушкина (1861-1904 гг.) и ряда других художников, творчеству большинства из которых не были чужды мотивы неорусского стиля. Основоположником этого течения в изобразительном искусстве следует назвать выдающегося русского живописца и архитектора В. М. Васнецова, разработавшего основы художественного языка неорусского стиля в живописи (станковая картина, храмовая стенопись, иконопись), графике (иллюстрация), декоративно-прикладном искусстве (орнамент, предметы мебели, эскизы костюмов), архитектуре (проекты дома В. М. Васнецова в Троицком переулке Москвы, фасада Государственной Третьяковской галереи, храма Спаса Нерукотворного в Абрамцеве).

Русский поэт, художественный критик и организатор художественных выставок С. К. Маковский (1877-1962 гг.) так писал об эффекте, который в сознании культурной публики произвело возвращение отечественного изобразительного искусства к национальным корням: «И мы это ясно сознаем именно теперь, когда начинаем освобождаться от пренебрежительного недоверия к художественным святыням прошлого, когда научились любить, чаруясь сказками Сурикова, Васнецова, Рябушкина, лучше, чем любили прежде народную красоту, красоту деревни - сказочный лепет далёких столетий» [1, с. 141].

Однако в творческом отношении задача гармоничной реинтерпретации «художественных святынь прошлого» оказалась исключительно сложной даже для наиболее одарённых мастеров - лишь единицам из них удалось изобразить на полотнах «лепет далёких столетий» с необходимой религиозно-философской глубиной и художественной силой, благодаря которым современники и потомки стали говорить о пышном расцвете русской национальной школы в искусстве, о становлении нового - русского (неорусского) - стиля, отличающегося оригинальностью художественных решений, комбинацией средств идейно-художественной выразительности.

Уточним содержание понятия «неорусский стиль» («русский стиль»), не имеющего к настоящему моменту однозначного варианта толкования в научной литературе. В терминологическом словаре «Аполлон» (1997 г.) представлено следующее определение термина «неорусский стиль»: «...стилевое направление, начионально-романтическая ветвь русского модерна, получившая наиболее полное воплощение в архитектуре, декоративно-прикладном искусстве и книжной графике, а также в сиенографии» [2, с. 388]. Согласимся с тем, что неорусский стиль условно можно назвать «ветвью русского модерна»; возражение вызывает другое: в перечисленных видах искусств отсутствует упоминание живописи - ни станковой, ни монументальной храмовой, ни театрально-декорационной, ни иконописи - хотя в живописи, на наш взгляд, художественные достижения неорусского стиля не менее очевидны. Ярким подтверждением этому могут служить, например, полотна, ставшие признанными вершинами станковой живописи: картины В. М. Васнецова («Сказка о спящей цуаревне» (1900-1926 г.), 
«Комей Бессмертный и Василиса Премудрая» (1917-1926 гг.), «Царевна-Лягушка» (1918 г.), «Сирин и Алконост. Сказочные птицы, песни радости и печали» (1896 г.)) и М. В. Нестерова («За приворотным зельем» (1888 г.), «Великий постриг» (1897-1898 гг.), «Юность преподобного Сергия» (1892-1897 гг.)). Показательны в этом отношении и образцы храмовой стенописи художников, как, например, в соборе Святого Владимира в Киеве, где работал В. М. Васнецов, а помогал ему М. В. Нестеров, а также в Марфо-Мариинской обители милосердия в Москве, где основные росписи исполнены М. В. Нестеровым, доверившим писать орнаментальные композиции П. Д. Корину [3, с. 86]. Эти зрелые плоды творческого труда воплощают в себе весь идейный универсум, всю стройную систему образов и символов, характерную для авторского художественного метода мастеров отечественного и мирового изобразительного искусства.

Почему именно В. М. Васнецова и М. В. Нестерова следует считать наиболее яркими представителя неорусского стиля, почему в творчестве именно этих двух художников стиль приобрёл совершенную визуальную гармоничность, идейную законченность и поразительную метафизическую глубину? На наш взгляд, ответ на этот вопрос невозможно дать без установления источника творческого влияния, каковым для живописцев стало искусство и культура Русского Севера, созерцание аскетичной красоты северной окраины государства. Русский Север - сокровищница национальной старины; такой статус северным землям Европейской части российского государства обеспечивает уникальное сочетание географического, исторического, и духовного факторов. Благодаря территориальной удалённости северных территорий от политического центра государства, трудным климатическим условиям (с суровыми и продолжительными зимами, обширными лесами, холодными реками и озёрами, малопроходимыми болотными топями и гатями) эти места всегда были малопривлекательными для среднего поселенца. В эпоху Киевской Руси северный край заселялся позже и медленнее среднерусских земель, но с началом татаро-монгольского ига окраинные северные земли приняли крупные миграционные потоки. Таким образом были созданы комфортные условия для сохранения на Русском Севере древнейших образцов, традиций, обычаев, обрядов русской культуры от инокультурного влияния. Здесь сохранились гидронимы, этимологически восходящие к языковым нормам времён Киевской Руси (реки Лыбедь, Почайна); характерные мотивы древнейших киевских росписей положены в основу художественного языка росписей прялок Русского Севера; сказы северян сохранили в себе узнаваемые сюжетные конструкции, персоносферу былин и легенд Киевской Руси. Во времена расцвета Новгорода Великого северный край входил в ареал культурных влияний Новгородской республики - это привело к распространению здесь традиций городской художественной культуры. Наконец, на Русском Севере столетиями складывался особый тип человека-мужественного, стойкого, трудолюбивого, почитающего заветы предков и обретающего силу в следовании этим заветам; от старожилов можно и сегодня услышать: «На веках стоим...». Слепком духовного облика северянина стала культура северной окраины государства с её специфическими символами и образами, воплощёнными в народном искусстве.

Многие из художественных метафор северной вышивки, росписи, резьбы, черни, скани, кружевоплетения, эмальерного искусства не разгаданы до сегодня, сокрыты в пластах многовековой народной памяти, но тем более важны те «философские мыслеобразы» северян, смысл которых ясен нашему современнику. Кратко охарактеризуем некоторые из них, а затем проследим, какую интерпретацию они получили в творчестве ведущих художников рубежа XIX-XX вв., работавших в неорусском стиле.

\footnotetext{
${ }^{1}$ Из личной беседы автора с жительницей г. Великого Устюга (23.07.2001 г.)

${ }^{2}$ Из личной беседы автора с И. С. Глазуновым, советским и российским художником-живописцем, педагогом, академиком Российской академии художеств (Москва, Россия), народным художником СССР (15.08.2004 г.)
} 
На наш взгляд, наиболее значимыми символами северного народного искусства следует считать образы, отражающие религиозно-философские основы мировоззрения северян, поскольку они позволяют судить об особенностях картины мира жителей Русского Севера, о распространённых в среде северян представлениях о смысле жизни, противоборстве светлых и темных сил, созидающих и разрушающих начал, берущих своё начало в православии. Таковы художественные образы-иносказания - Процветший крест, Древо жизни или Мировое древо, Райская птица (птицы Сирин и Алконост, птицы-павы), каждый из которых отражает связь небесного/высшего, земного и подземного миров.

Заметное место в мировоззрении северян занимают образы охранителей рода, дома, земли от зла - русалки-берегини, львы, симарглы (полканы, китоврасы), - нашедшие своё отражение в северных сказах, в песнях, изобразительном искусстве. Эти образы - исконные для народного творчества жителей Русского Севера, произведения которого воспринимались созерцателем как нечто, существующее в неразрывной связи с его повседневной жизнью, вплетённое в неё многовековой народной памятью, одобренное крепкими северными традициями, нуждавшимися в наследовании, продолжении. Образцы росписи, резьбы или вышивки развивали символический ряд песен, легенд, сказов, повествующих о главных духовных ценностях жизни.

Художникам рубежа XIX-XX вв. непросто было воспринять мудрость этого иносказательного повествования, соединить его с собственной духовной жизнью, найти точки соприкосновения с гражданскими настроениями и культурными потребностями своих современников, совершить прорыв к высотам истинно национального искусства. Решение такой творческой сверхзадачи оказалось под силу очень немногим. Некоторая часть отечественных художников приезжала на окраинные земли, писали этюды с натуры, на основе которых создавали живописные полотна и графические произведения, однако лишь единицам их них удалось в совершенстве овладеть подлинным художественным языком северного искусства.

Среди художников России, отметившихся работами в неорусском стиле, наиболее глубоко и полно постичь образы северного народного искусства, вдохновенно и самобытно выразить их в своём индивидуальном творчестве, по нашему убеждению, смогли, прежде всего, уже упомянутые выше В. М. Васнецов и М. В. Нестеров, а также И. Я. Билибин (18761942 гг.), а также отчасти К. А. Коровин (1861-1938 гг.) [4, с. 172] и Л. М. Прянишников (1940-1894 гг.). Прочие отечественные живописцы, графики, архитекторы и скульпторы, представившие в своих произведениях авторские интерпретации северных мотивов, либо повторяли художественные достижения вышеперечисленных мастеров, либо ограничивались изображением видов Русского Севера, либо не поднимались в своём художественном поиске выше технического копирования элементов оригинального народного искусства северян.

Как и почему именно эти художники научились «говорить» на языке традиционного искусства Русского Севера? Обращаясь к биографиям живописцев, можно заметить, что все они в разное время испытали на себе сильное влияние самобытных художественных традиций окраинных земель России. Так, детские и юношеские годы В. М. Васнецова и И. М. Прянишникова, их семей связаны с северным краем, становление идейноэстетических представлений будущих художников о природе искусства сформировались под определяющим воздействием традиционной культуры северян. И. Я. Билибин, М. В. Нестеров и К. А. Коровин, не связанные с Русским Севером по происхождению, были частыми гостями этих земель, живо интересовались бытом и культурой северной жизни, образцами местного изобразительного искусства, угадывая в работах безымянных народных художников константы национальной культуры.

Творческая эволюция мастеров изобразительного искусства, явившаяся результатом тесного контакта с художественной культурой Русского Севера, протекала по схожему сценарию: каждый их живописцев поработал в жанре пейзажного этюда, воспроизвёл в своих работах специфические черты северной храмовой и избяной архитектуры, постигал композиционные каноны, систему пропорций и нормы колорита по образцам местного народного 
искусства, усваивал принципы стилистического аскетизма иконописи и стенописи, активно заимствовал символику и элементы художественного языка северного декоративноприкладного искусства, характерные для произведений, выполненных в неорусском стиле. Духовные традиции Русского Севера находили благодарных восприемников в лице выдающихся отечественных художников, талантливо сочетавших самобытный изобразительный язык северян с собственным творческим «почерком».

Обратимся к примерам живописных произведений в неорусском стиле, кратко охарактеризуем историю рождения художественных образов, идейный замысел работ. Рассмотрим графическую композицию «Чёрный всадник» (1900 г.) И. Я. Билибина, полотна «Спящая изаревна» В. М. Васнецова и «Лисичка» (1914 г.) М. В. Нестерова. Обращаясь к разным средствам художественной выразительности и несхожим технико-технологическим приёмам конструирования изображения, авторы создают удивительно созвучные друг другу «по духу» и атмосфере работы, вошедшие в сокровищницу русского национального изобразительного искусства. Всех авторов объединяет неподдельная искренность в творчестве; М. В. Нестеров писал: «Виктор Михайлович Васнецов был истинным художником и никем и ничем иным быть он не мог» [5, с. 65] - эта характеристика, несомненно, справедлива и в отношении всех трёх вышеназванных мастеров кисти. Их произведения, авторский идейный посыл которых без труда считывается даже неподготовленным зрителем, отличает богатое религиознофилософское содержание, воплощённое с помощью вневременных образов-символов Русского Севера: величественных видов далёких земель: лесов, стоящие «тёмной стеной», словно ряды воинов, холмов и взгорий с замшелыми валунами, с которых открывается широкий простор на холодные реки, тёмные избы и терема. Каждая деталь таких произведений одновременно и лаконична, и многоречива, поскольку в точно угаданной художественной форме художнику удалось заключить богатство народной мудрости северян, вневременные смыслы народного искусства, представлений жителей Русского Севера о смысле жизни, годовых и жизненных циклах, добре и зле, вере в торжество светлых сил и созидающего начала. Таковы универсальные образы-символы северной земли и всей Руси: православный храм на речном взгорье, фигура седого монаха, деревья-великаны, обвеваемые холодными ветрами, сложная композиция северного узорочья, вдохновлённая образами и символами православной культуры (Процветший Крест и Мировое Древо).

В подтверждение вышесказанного представим результаты анализа образного строя иллюстрации И. Я. Билибина «Чёрный всадник» к русской сказке «Василиса Прекрасная», в которой художник воплощает своё видение мира русской старины, собирательный образ Русского Севера. В рисунке узнаваем характерный пейзаж окраинных земель - тёмная чаща, чёткий контур еловых вершин в контражуре, напротив закатного солнца, едва проходимые заросли папоротника, через которые пробирается, осторожно ступая, чёрный конь. Орнаментальная рама рисунка выполнена в весьма характерной для художественной традиции Русского Севера манере: здесь сочетаются стилизованные образы птиц Сиринов, взятые из декоративно-прикладного искусства северян, элементы традиционного орнамента, напоминающие, например, вышивку «деревами», а также элементы полурозеток, часто встречающиеся в деревянной резьбе обитателей северного края. Подобные орнаментальные мотивы находим в образцах традиционного искусства Севера. Например, роспись Пермогорской прялки объединяет изображения и птицы Сирин, и розетки (вторая половина XIX в., Северная Двина) [6, c. 61]; в трёхгранно-выемчатой резьбе каргопольской прялки сочетаются различные варианты полихромных розеток - подобия солярных знаков, символические воплощения годового цикла, целостности мира и его вечных устоев [6, с. 99]; образ Птицы Сирин в сочетании с растительными мотивами, тождественный трактовке И. Я. Билибина, орнаментальные заставки церковно-богослужебной литературы Выговской пустыни XIX в.: псалтыри, минеи, святцев [6, с. 59]. Подобны детали иллюстраций - геометрические орнаментальные построения характерны для вологодских вышивок, например, для декора северных рубах (кон. XIX в., Госу- 
дарственный Русский музей, К-3588; 1910-е гг., мастер О. П. Замыслов, Кадниковский уезд Вологодской губернии, Государственный Русский музей, К-407) [7, с. 166].

Таким образом, в решении иллюстрации «Чёрный всадник» И. Я. Билибин профессионально применяет сложно-синтезированный художественный язык, вобравший в себя отчасти натуралистичное, отчасти стилизованное отображение северного пейзажа, гармонично комбинирует собственный «творческий почерк» (характер рисунка, колористический строй, внимание к деталям) с канонами изображения элементов декоративно-прикладного искусства Русского Севера, наполненных метафорическими смыслами. Следовательно, бесконфликтное сочетание языков индивидуального (профессионального) и коллективного (традиционного) творчества достижимо; более того: именно благодаря опоре авторской творческой манеры на художественные традиции прошлого произведение И. Я. Билибина приобретает многоплановое звучание - художник ведёт зрителя через чащу тёмного северного леса, к древним образам-символам народного искусства, в котором северяне в лаконичной художественной форме выражали своё понимание глубинных смыслов мироустройства, облик национальной духовной жизни, неотделимой от православного вероучения.

Если в своём творчестве И. Я. Билибин ограничивается намёками на эти темы, то в произведениях В. М. Васнецова и М. В. Нестерова они звучат в полную силу подтверждение этому находим, в частности, в решении одного из самых известных живописных полотен В. М. Васнецова «Спящая царевна» (собрание Дома-музея В. М. Васнецова в Москве). Художник работал над ним 26 лет - до последнего дня (а, возможно, и до последнего часа) своей жизни, которая оборвалась утром 23 июля 1926 г. Полотно «Спящая цзаревна» тогда, как и ныне, находилось в его мастерской, сам автор не считал его законченным. Есть основания предполагать, что это произведение было особенно дорого художнику, поскольку в нём ему удалось на языке изобразительного искусства, прибегнув мотивам народного художественного творчества Русского Севера, выразить свои сокровенные мысли о вневременных духовно-художественных ценностях Руси. Сам В. М. Васнецов родился в с. Лопьял Уржумского уезда Вятской губернии - в пограничье Русского Севера. В своих автобиографических заметках мастер писал: «Сын священника. Образование получил в Вятской духовной семинарии» [8, с. 250]. Народное искусство и культурные традиции, обряды вятских земель были ему известны с детства; художник, словно впитав в себя образы окраинных земель, пронёс их через всю свою жизнь, воплотил во многих своих произведениях через колористические решения, композиционную специфику рисунка, интерпретацию деталей, портретные характеристики.

В «Спящей царевне» об искусстве Русского Севера напоминают архитектурные объекты - подобия храмов, теремов, изб окраинных земель, народные костюмы, элементы местной резьбы и росписи. В. М. Васнецов был глубоко верующим человеком, православным художником, поэтому закономерно, что главного персонажа картины - спящую царевну - он трактует как воплощение Святой Руси, уснувшей, но не погибшей, не утратившей связи с традициями старины, мудростью народной веры и искусства. Рядом с главным персонажем картины художник помещает фигуру девочки, уснувшей на «Голубиной книге» (иначе «Глубинной книге», «Каменной книге») - сборнике народных духовных стихов; строки, на которых раскрыта книга, могут быть прочитаны зрителем: «У нас белый вольный свет зачался от Суда Божьего»-художник сообщает метафизическую глубину художественному образу. Н. А. Ярославцева, характеризуя творчество В. М. Васнецова, замечает: «Искания Божьей Правды в русском искусстве второй половины ХІХ века явились духовной основой формирования национальной школы живописи» [9, с. 136].

От иносказательного образа православной Руси, характерного для произведений В. М. Васнецова, обратимся к её ясно решённой визуальной трактовке, лаконичной, чёткой, глубоко осознанной, представленной в работах М. В. Нестерова. Он, как мало кто в отечественном искусстве, смог передать в живописи «синергизм духовного пространства» Русско- 
го Севера [10, с. 181]. Воплощение духовной красоты Святой Руси стало главной целевой установкой его творчества, для её достижения художник обращается к библейским сюжетам в стенописи и станковой живописи, фокусирует внимание зрителя на лицах-ликах монахов, послушниц, путников, простолюдинов. Работы М. В. Нестерова в портретном жанре следуют той же цели: в своих героях художник ищет образ Святой Руси; так, например, для написания картины «Философы (С. Н. Булгаков и П. А. Флоренский)» (1917 г.) он приглашает выдающихся современников - столпов религиозно-философской мысли, один из которых вскоре эмигрирует во Францию, а другой спустя несколько лет погибнет в Соловецком лагере особого назначения.

Не менее убедительно о духовной красоте православной Руси художник сумел сказать изображая русский пейзаж. Одна из картин М. В. Нестерова - «Лисичка»- представляет собой аутентичное воплощение вневременной сути Русского Севера, характера северян, воспитанного православием, ценящего милосердие и добротолюбие; взгляд на картину в христианской оптике позволяет за изображением рядовой сцены из жизни трёх путешествующих монахов почтенного возраста увидеть метафизические смыслы в могучем просторе сурового северного пейзажа, широком разливе холодной неподвижной реки, мягком выражении лиц путников, умиляющихся доверчивости дикого лесного зверя, бесстрашно вышедшего им навстречу.

В заключение ещё раз подчеркнём: становление эстетических канонов неорусского стиля происходило под определяющим влиянием народного изобразительного искусства Русского Севера, художественные образы которого воплощают в себе фундаментальные для русской культуры религиозно-философские смыслы. Творчество отечественных художников рубежа XIX-XX вв., вдохновлённое стилистикой искусства жителей северного края, позволило вновь «открыть» для современников и потомков художественные идеалы и традиции исторической Руси. Северные земли российского государства впервые были осознаны как заповедники исконной русской культуры, сокровищница русской старины, незамутнённый источник самобытной художественной традиции.

\section{Сиисок литературы}

1. Маковский, С. К. Силуэты русских художников. - Москва : Респ., 1999. - 383 с. : ил., портр.

2. Аполлон. Изобразительное и декоративное искусство. Архитектура : терминолог. словарь : А-Я / под ред. А.М. Кантора. - Москва : Эллис Лак, 1997. - 735 с. : ил.

3. Скоробогачева, Е. А. Стенопись М. В. Нестерова в Марфо-Мариинской обители - синтез художественных традиций и духовная целостность / Е. А. Скоробогачева, В. Ю. Захаров // Зубовский вестник. 2019. - № 3. - С. 69-89.

4. Скоробогачева, Е. А. Мотивы Русского Севера в творчестве К. А. Коровина: эволюция художественного языка // Исторические, философские, политические и юридические науки, культурология и искусствоведение. Вопросы теории и практики. - 2015. - № 8, ч. 3. - С. 168-172.

5. Нестеров, М. В. Давние дни: Встречи и воспоминания. - Москва : Русская книга, 2005. 559 с. (Русские мемуары. Москва и москвичи).

6. Народное искусство. Русская традиционная культура и Православие. XVIII-XXI вв.: традиции и современность / под ред. М. А. Некрасовой. - Москва : Союз дизайн, 2013. - 623 с. : цв. ил.

7. Народное искусство. Государственный Русский музей. Материалы и исследования : сб. ст.Вып. II / под ред. И. Я. Богуславской. - Санкт-Петербург : Palace Editions, 2005, - 184 с. : цв. ил.

8. Васнецов, В. М. Письма. Дневники. Воспоминания. Документы. Суждения современников.Москва : Искусство, 1987. - 496 с. : цв. ил., портр.

9. Ярославцева, Н. А. Москва Виктора Васнецова: (История души художника). - Москва : Фонд «Мир русской души», 1998. - 158 с. : ил., портр.

10. Скоробогачева, Е. А. Синергизм духовного пространства Русского Севера в формировании личности и философии искусства М. В. Нестерова // Исторические, философские, политические и юридические науки, культурология и искусствоведение. Вопросы теории и практики. - 2015. - № 5, ч. 1. - С. 181-185. 
Ekaterina A. Skorobogacheva, Dr. of Art Criticism

Ilya Glazunov Russian Academy of Painting, Sculpture and Architecture (Moscow, Russia) skorobogacheva@mail.ru

\title{
TRADITIONAL CULTURE OF THE RUSSIAN NORTH IN NEO-RUSSIAN STYLE GENESIS
}

\begin{abstract}
The article reviews historical and cultural context of appearance of Neo-Russian style focused on re-thinking traditions of Ancient Russian visual art in Russian art of the turn of the 19th and 20th centuries. The author outlines her own point of view on a role of system of graphic and expressive means elaborated in people's art of the Russian North in becoming aesthetic canons on the Reo-Russian style. The key peculiarities of artistic language that is very representative for the greatest Russian painters famous for their masterpieces in Neo-Russian style, such as Viktor Vasnetsov (1848-1926), Mikhail Nesterov (1862-1942), Ivan Bilibin (1876-1942), by are analyzed in the paper.

Kyewords: The Russian North, Russian people's culture, artistic language of visual art of the Russian Nortyh region, Viktor Vasnetsov (Russian painter), Mikhail Nesterov (Russian painter), Ivan Bilibin (Russian painter), Neo-Russian style, Modern in art, Orthodox Christianity in secular art.
\end{abstract}

